\title{
Considerações sobre as Inquirições \\ Devassas no Brasil: os casos do Recôncavo Baiano - Séculos XVIII e XIX
}

\section{Considerations on the Inquiries Devassas in Brazil: the Cases of the Recôncavo Baiano $-18^{\text {th }}$ and $19^{\text {th }}$ Centuries}

\section{Ana Lúcia Sabadell ${ }^{1}$}

Faculdade Nacional de Direito, Universidade Federal do

Rio de Janeiro, Rio de Janeiro/RJ, Brasil

anasabadell@yahoo.com

http://lattes.cnpq.br/5937607531425854

https://orcid.org/0000-0001-9370-1057

\section{Júlio Cesar Costa Manoel ${ }^{2}$}

Secretaria de Educação do Estado do Rio de Janeiro, Rio de Janeiro/RJ, Brasil

juliocesarmanoel@yahoo.com

http://lattes.cnpq.br/2296912699086021

https://orcid.org/0000-0002-4217-7336

Resumo: Este artigo busca contribuir com o debate sobre as etapas iniciais do processo penal no Brasil durante o período colonial e os primeiros anos do Império. Focaremos nossa análise nas Inquirições

1 Graduação em Direito pela Pontifícia Universidade Católica de São Paulo (1986); Graduação em Psicologia pela Universidade São Marcos (1987); Mestrado em Direito - Universidad Autónoma de Barcelona - Espanha (1991); Mestrado em Critical Criminology and Criminal Justice - Programa Erasmus - Universität des Saarlandes (1998); Doutorado em Direito - Universität des Saarlandes (1999) e pós-doutorado na Universidade Politécnica de Atenas (Grécia) em 2002. Atualmente é professora titular de teoria do direito da Faculdade Nacional de Direito da Universidade Federal do Rio de Janeiro.

2 Graduação em Geografia pela Universidade Estadual do Rio de Janeiro (2010); Graduação em Direito pela Universidade Federal do Rio de Janeiro (2014); Mestrado em Direito - Universidade Federal do Rio de Janeiro (2019); Professor Regente da Rede Estadual do Rio de Janeiro. 
Devassas, poderosos meios de investigação, que sem a anuência da pessoa acusada, inquiria testemunhas e produzia provas sobre delitos cometidos. Regulamentadas pelas Ordenações Portuguesas, estas foram utilizadas como ferramenta de controle social do Estado sobretudo frente aos escravizados e a população livre mais pobre. Apresentaremos dados relativos a 89 processos criminais ocorridos na região do Recôncavo Baiano e que tramitaram durante o período colonial até o pós-independência, no ano de 1832, quando entrou em vigor o Código de Processo Criminal que extinguiu definitivamente a possibilidade de tirar inquirições devassas no Brasil.

Palavras-chaves: Inquirições Devassas; Processo Criminal; Delitos.

ABSTRACT: This article aims to contribute to the debate on the initial stages of criminal procedures in Brazil during the colonial period and the early years of the Empire. The focus of our analysis is on the Inquiries Devassas, powerful means of investigation, which without the consent of the accused person, questioned witnesses and produced evidence of committed crimes. Regulated by the Portuguese Ordinations, the inquiries were used as a tool for social control of the State, especially in relation to the enslaved and the poorest free population. We will present data related to 89 criminal cases that took place in the Recôncavo Baiano region and that were processed during the colonial period until the post-independence period, in 1832 when the Code of Criminal Procedure entered into force, which definitively extinguished the possibility of removing the inquiries in Brazil.

KeYwords: Inquiries Devassas; Criminal Proceedings; Offenses.

SUMÁRIO: Introdução; 1.1. Procedimentos das inquirições devassas; 1.2. Inquirições devassas na sociedade colonial do Brasil; 2. Os casos da região do Recôncavo Baiano; 2.1. Dados gerais sobre a origem dos processos penais; 2.2 As inquirições devassas; Conclusão; Referências.

\section{INTRODUÇÃo}

O presente artigo possui como objetivo central contribuir com o estudo sobre as Inquirições Devassas no Brasil, analisando processos criminais julgados entre o início do século XVIII e primeiras décadas 
do século XIX. Estes ocorreram no Recôncavo Baiano e tramitaram nos órgãos judiciais locais de primeira instância que estavam sob a jurisdição do Tribunal da Relação da Bahia.

Neste trabalho apresentamos os primeiros resultados dessa pesquisa, indicando algumas das características centrais destes processos e situando-os no seu momento histórico. Trata-se de 89 processos criminais, sendo aproximadamente $70 \%$ correspondentes a devassas, também conhecidas no período histórico pelo sinônimo inquirição, 26\% correspondentes a casos iniciados com querelas e $4 \%$ correspondentes a processos sumários que não se originaram a partir de devassa ou querela.

Durante o nosso recorte, a região do Recôncavo Baiano esteve em constante ebulição econômica e social. Localizada no entorno da Bahia de Todos os Santos, se caracterizou nos séculos XVIII e XIX como um importante entreposto comercial através da produção de açúcar para exportação e também de gêneros alimentícios que visavam abastecer a capital Salvador e o mercado interno da colônia ${ }^{3}$.

Devido ao desenvolvimento econômico e à expansão dos engenhos de açúcar a região também ficou marcada pela escravização de seres humanos oriunda do tráfico de negros da África para o Brasil e pelas revoltas e rebeliões dos escravizados frente ao sistema de desumanização a que foram expostos ${ }^{4}$.

A grande maioria dos casos que estudamos, cerca de $84 \%$, se iniciaram na localidade de Cachoeira. Esta vila, além da produção de açúcar, se especializou na cultura do fumo, que era uma importante moeda de troca por escravizados nos portos africanos ${ }^{5}$. Os outros 16\% dos casos se espalharam pelas localidades de Geremoabo, Salvador, Vila de São Francisco da Barra de Sergipe do Conde, Arraial de Monte Santo,

3 Ver: BARICKMAN, Bert. Um contraponto baiano: açúcar, fumo, mandioca e escravidão no Recôncavo, 1780-1860. São Paulo: Civilização Brasileira, 1998.

4 Ver: SCHWARTZ, Stuart B. Segredos internos: engenhos e escravos na sociedade colonial, 1550-1835. São Paulo: Companhia Das Letras, 1985. e REIS, João José. Rebelião escrava no Brasil: a história do levante dos malês. São Paulo: Brasiliense, 1986.

5 REIS, João José. Recôncavo rebelde: revoltas escravas nos engenhos baianos. Afro-Asia, v. 15, p. 100-126, 1992, p. 100. 
Itapirucu de Cima, Vila de São João de Água Fria, Vila de Nossa Senhora de Jaguaribe, Pilão Arcado e Alagoinhas.

Todos os processos aqui citados estão perfeitamente inseridos na lógica de produção colonial, se vinculando às determinações processuais e legais da metrópole. Analisando especificamente nosso objeto, podemos observar que, na história do direito processual penal português e brasileiro, o termo devassa sempre esteve atrelado ao ato de inquirir testemunhas acerca de um delito cometido ou suspeitado ${ }^{6}$. Nesse sentido, as Ordenações Portuguesas, juntamente com comentários de juristas como Mendes De Castro (1661) Cabral (1730), Leitão (1736), Ferreira (1767), Melo Freire (1794) e Pereira e Souza (1825), se ocuparam de regulamentar e analisar os dispositivos processuais e legais inerentes às inquirições devassas, especialmente a partir do século XVI.

As devassas se inseriram em um modelo de direito processual inquisitorial, onde o magistrado pôde tomar parte ativa na averiguação da verdade (Ord. Filipinas, livro V, CXXIV, 7) ${ }^{7}$. Assim, o corpo de delito era uma ferramenta de investigação. Este recebeu grande notoriedade, destacando-se como elemento fundamental da peça processual na busca de se obter respostas para a investigação. Nos processos estudados, em apenas nove casos não foram realizados os exames de corpo de delito. Em todos os outros este se caracterizou como fundamental para o desenvolvimento da inquirição.

Cientes da importância das devassas e de sua utilização como ferramenta processual no Brasil, em especial em nosso recorte temporal e espacial, buscaremos apresentar os elementos principais deste instituto a partir dos casos processuais analisados.

Para atender nosso objetivo indagamos: como as devassas, originadas no direito português, foram utilizadas no Brasil para atender aos interesses da administração colonial? Esses instrumentos adquiriram no Brasil condições e características próprias? E ainda, identificando as

6 FARIA, Eduardo. Novo dicionário da língua portuguesa. $4^{\mathrm{a}}$ ed. v. 2. Rio de Janeiro: Typographia Imperial e Constitucional, 1859, p. 1096.

7 Sobre as características do processo penal na idade média e moderna, ver, dentre outros: SABADELL, Ana Lúcia. Tormenta Iuris Permissione. - Tortura e processo penal na Península Ibérica. Rio de Janeiro: Revan, 2007. 
devassas como instrumentos de poder e informação, quais os elementos processuais, legais e sociais podem ser destacados ao analisarmos os casos de inquirição nos processos penais que recortamos?

Este estudo não é definitivo e não possui a intenção de esgotar o tema, ao contrário visa contribuir para os debates sobre as devassas e o processo penal no Brasil. Acreditamos que a análise destes dados se desdobrará em diferentes pesquisas, nas quais poderemos decompor, detalhadamente, cada um dos casos, gerando contribuições significativas para a história do nosso direito.

Para atender ao objetivo específico deste estudo, seguiremos como princípio metodológico o entrelaçamento de fontes primárias, como as Ordenações portuguesas adotadas no Brasil e autos de devassa disponíveis para consulta no Arquivo Público do Estado da Bahia (APEB) nas seções colonial e judiciária, com autores já citados que escreveram suas obras no século XVII, XVIII e XIX, seguido de obras contemporâneas como Almeida Júnior (1959), Pierangelli (2001), Wehling e Wehling (2004), Fernandes (2005) e Martins (2010).

Ao realizar essas etapas dividiremos nossa pesquisa nos seguintes momentos: no primeiro faremos uma análise geral das inquirições devassas e buscaremos apresentar elementos de suas particularidades no Brasil. No segundo momento apresentaremos os dados gerais dos documentos selecionados para esta investigação, expondo casos específicos onde podemos identificar elementos típicos dos processos criminais da região do recôncavo baiano.

\section{1- As INQUIRIções deVASSAS No BrasiL}

As Inquirições Devassas aplicadas no Brasil são oriundas do direito português, havendo referências às mesmas nas Ordenações Manuelinas, de 1521. Estas são apresentadas como uma etapa do processo penal português, nas quais as verificações de crimes feitas de ofício poderiam se estender a pessoas suspeitas ou acusadas sem que elas fossem citadas ${ }^{8}$.

8 As Ordenações Manuelinas estabeleceram no Livro I, título XLIV, item I os casos em que os, corregedores, ouvidores e juízes deveriam tirar inquirições devassas. 
Estas regras foram vigentes nos primeiros anos da colônia brasileira9 ${ }^{9}$, porém, devido à falta de organização estrutural e institucional da América Portuguesa as determinações eram estabelecidas seguindo as particularidades e necessidades dos governadores das capitanias hereditárias, os quais nomeavam ouvidores para aplicar a justiça ${ }^{10}$.

Assim a aplicação das Ordenações Manuelinas em um território tão grande, disperso e distante de Portugal, como o Brasil, foi realizada de maneira lenta e diversificada, variando de acordo com o processo de afirmação da autoridade real em cada capitania ${ }^{11}$.

Estas Ordenações foram revogadas pelas Ordenações Filipinas ${ }^{12}$, promulgadas em 1603, durante a União Ibérica sob o reinado de Felipe II. Este novo ordenamento se caracterizou por unir ao antigo diploma legal uma série de leis extravagantes, proporcionando uma atualização do direito vigente em Portugal ${ }^{13}$ e, por consequência, nas colônias.

A vigência destas leis no Brasil perdurou para efeitos penais e processuais penais até o período Imperial, quando entraram em vigor respectivamente o Código Criminal em 1830 e de Processo Criminal em 1832, revogando-as expressamente.

Herdadas das Ordenações Manuelinas, com origem na inquisição típica do direito canônico ${ }^{14}$, as devassas permaneceram vigentes no pro-

9 WEHLING, Arno; WEHLING, Maria José. Direito e Justiça no Brasil Colonial O Tribunal da Relação do Rio de Janeiro (1751-1808). Rio de Janeiro: Renovar, 2004, p. 44.

10 PIERANGELI, José Henrique. Códigos Penais do Brasil: evolução histórica. 2. ed. São Paulo: Revista dos Tribunais, 2001. p. 61.

11 WEHLING, Arno; WEHLING, Maria José. Direito e Justiça no Brasil Colonial O Tribunal da Relação do Rio de Janeiro (1751-1808). Rio de Janeiro: Renovar, 2004, p. 42.

12 As Ordenações Filipinas eram organizadas nos seguintes livros: Livro I (Direito Administrativo e Organização Judiciária); Livro II (Direito dos Eclesiásticos, do Rei, dos Fidalgos, e dos Estrangeiros); Livro III (Processo Civil); Livro IV (Direito Civil e Direito Comercial); Livro V (Direito Penal e Processo Penal).

13 COSTA, Célio; LEMES, Amanda; MONTAGNOLI, Gilmar. Processo civilizador e legislação: considerações sobre as Ordenações Portuguesas. Revista Educação e Fronteiras On-Line, v. 1, p. 118-129, 2011, p. 124.

14 OLIVEIRA, António Braz de; MARINHO, Maria José. Devassa a que mandou proceder Sua Magestade no território do Alto Douro pelo Desembargador Antonio 
cesso penal do Brasil durante todo esse período garantindo a legalidade do instrumento autoritário, onde a investigação ${ }^{15}$ não exigia a presença da pessoa acusada ${ }^{16}$.

Ao estudar a institucionalização das devassas, Martins ${ }^{17}$ nos apresenta o cenário onde o Brasil, no início de sua colonização, estava marcado pela precarização da estrutura logística e burocrática que inviabilizava o exercício das inspeções e correições do Ouvidor-Geral permitindo que a justiça fosse administrada localmente.

Visando aumentar a centralização do poder na colônia, foi instalado em 1609 o Tribunal da Relação da Bahia. Apoiado em razões econômicas, com o aumento da exploração da cana de açúcar e militares, a metrópole propendia ampliar as inspeções e controlar a administração local garantindo que os governadores, proprietários de terras e ouvidores locais agissem de acordo com o interesse da coroa.

Segundo Schwartz ${ }^{18}$, o Tribunal da Relação da Bahia tinha a intenção de aumentar os poderes da metrópole sobre a colônia visando reduzir o poder local. Contudo, o conflito de interesses com a elite colonial somada aos seus custos de manutenção durante o período das

de Mesquita e Moura. Lisboa: Biblioteca Nacional, 1983, p. XLII e FREIRE, Pascoal José de Melo. Instituições de direito criminal português. Tradução de Miguel Pinto de Menezes. Boletim do Ministério da Justiça, n. 155-156, Lisboa, Ministério da Justiça, 1966, p. 92.

15 É importante destacar que a Igreja Católica influenciou diretamente na forma como os diversos territórios europeus realizaram seus procedimentos de inquirição de faltas e crimes. A forma era semelhante à inquirição realizada por bispos nas dioceses, servindo esta de inspiração para dar autenticidade às investigações de autoria e materialidade dos delitos (RIBEIRO, Ludmila Mendonça; DUARTE, Thais Lemos. Do processo penal colonial a reforma processual penal de 2008: análise sócio-histórica do Sistema de Justiça Criminal brasileiro. Interseções - revista de estudos interdisciplinares, v. 13, n. 1, p. 40-64, 2011, p. 44).

16 ALMEIDA JUNIOR, João Mendes de. Processo criminal brasileiro. Volume I. 4. ${ }^{\mathrm{a}}$ ed. São Paulo: Freitas Bastos, 1959, p. 112.

17 MARTINS, Lucas Moraes. Uma genealogia das devassas na história do Brasil. In: XIX Congresso Nacional do CONPEDI, 2010, Fortaleza. Anais do XIX Congresso Nacional do CONPEDI. Fortaleza: Fundação Boiteux, 2010, p. 6041.

18 SCHWARTZ, Stuart B. Burocracia e sociedade no Brasil colonial: a suprema corte da Bahia e seus juízes: 1609 - 1751. $1^{\mathrm{a}}$ ed. Trad. Maria Helena Pires et al. São Paulo: Editora Perspectiva, 1979, p. 173-185. 
invasões holandesas (1624 e 1625) suspendeu o funcionamento do Tribunal no Brasil. Este só foi reestabelecido em 1652, com o governador geral exercendo a função de fiscalização sobre governadores e membros do tribunal ${ }^{19}$. A presidência ficava a cargo do Chanceler que tinha a competência para analisar as decisões do Governador Geral e, em caso de divergência, o Tribunal era convocado para decidir a questão. Essa estrutura foi criada para manter a burocracia colonial sob o controle da metrópole ${ }^{20}$.

Ao longo de sua existência o Tribunal da Relação da Bahia desempenhou funções muito além das de cortes de primeira instância ou de apelação, exercendo poder e influência sobre órgãos jurídicos e administrativos no Brasil ${ }^{21}$. Cabe a nós neste trabalho investigar a questão das devassas, instrumentos importantes de controle administrativo e social que foram efetuadas pelos magistrados que estavam sobre a sua jurisdição.

As devassas se caracterizaram como uma parte fundamental do processo criminal da colônia ${ }^{22}$ e foram reguladas pelas Ordenações Filipinas no seu livro 1 título $65^{23}$ sendo definidas no mesmo ordenamento, a partir dos ensinamentos de Pereira de Sousa ${ }^{24}$, como "o acto jurídico,

19 VALIM, Patrícia. O Tribunal da Relação da Bahia no final do século XVIII: politização da justiça e cultura jurídica na Conjuração Baiana de 1798. Tempo, v. 24, n. 1, p. 117-139, 2018, p. 118.

20 MARTINS, Lucas Moraes. Uma genealogia das devassas na história do Brasil. In: XIX Congresso Nacional do CONPEDI, 2010, Fortaleza. Anais do XIX Congresso Nacional do CONPEDI. Fortaleza: Fundação Boiteux, 2010, p. 6042.

21 WEHLING, Arno; WEHLING, Maria José. Direito e Justiça no Brasil Colonial O Tribunal da Relação do Rio de Janeiro (1751-1808). Rio de Janeiro: Renovar, 2004, p. 39.

22 Segundo Pereira e Sousa, o processo criminal do Império consistia na indagação dos delitos e no castigo. A devassa era o modo principal de indagação dos delitos no reino (PEREIRA e SOUSA, Joaquim Jose Caetano. Primeiras linhas sobre o processo criminal. $3^{\mathrm{a}}$ ed. Lisboa: Typo. Rollandiana, 1820, p. 19). ORDENAÇÕES FILIPINAS, Livro I, Título LXV: Dos Juízes ordinários e de fora Casos de devassa.

24 PEREIRA e SOUSA, Joaquim Jose Caetano. Esboço de hum diccionario juridico, theoretico, e practico: remissivo às leis compiladas, e extravagantes. Lisboa: Typographia Rollandiana, 1825; ORDENAÇÕES FILIPINAS, Livro I, Título LXV. 
pelo qual se inquirem testemunhas por autoridade do Juiz para informação de algum delicto, afim de ser punido o delinquente, e manter-se a tranquillidade publica”.

\subsection{Procedimentos dAS INQUIRIÇõES DEVASSAS}

As devassas faziam parte de um rito processual ${ }^{25}$ de acusação. Ao ser determinada, prosseguia-se com uma investigação sigilosa sem o conhecimento da pessoa acusada. Após esta etapa fazia-se o indiciamento (pronúncia do réu) e interrogatório do réu, que poderia negar as acusações exigindo a oitiva das testemunhas novamente. Em caso de confissão o juízo proferia a decisão, caso contrário apresentava-se testemunhas de defesa. Ao final eram apresentadas as razões de defesa e acusação e proferia-se a sentença ${ }^{26}$ e desta decisão cabia apelação ${ }^{27}$.

As devassas eram divididas em devassa geral ou especial. Segundo o texto das Ordenações Filipinas: "à primeira se tirava sobre delicto

25 Wehling e Wehling, analisando as Ordenações Filipinas e autores como Cabral (1730) e Freire (1966) nos apresentam que: o processo ordinário penal no Brasil colonial seguia os seguintes passos em caso das devassas e querelas: denúncia - inquirição - pronúncia do réu (acusação) - agravo de injusta pronúncia ou prisão - requerimento de carta de seguro confessativa ou negativa ou alvará de fiança - primeira audiência - libelos - Segunda audiência - tréplicas - dilações - razões finais - conclusão - sentença - trânsito em julgado ou apelação. Observe-se que o réu ou o autor poderiam impetrar diferentes agravos ao longo do processo. Em síntese, pode-se caracterizar as grandes etapas processuais como sendo a inquirição (cujo objetivo era a formação do corpo de delito), o indiciamento do autor do crime (com a pronúncia do réu), a prisão, a acusação (compreendendo as audiências e razões finais), a sentença e a apelação (WEHLING, Arno; WEHLING, Maria José. Direito e Justiça no Brasil Colonial - O Tribunal da Relação do Rio de Janeiro (1751-1808). Rio de Janeiro: Renovar, 2004, p. 565).

26 RIBEIRO, Ludmila Mendonça; DUARTE, Thais Lemos. Do processo penal colonial a reforma processual penal de 2008: análise sócio-histórica do Sistema de Justiça Criminal brasileiro. Interseções - revista de estudos interdisciplinares, v. 13, n. 1, p. 40-64, 2011, p. 45.

27 WEHLING, Arno; WEHLING, Maria José. Direito e Justiça no Brasil Colonial O Tribunal da Relação do Rio de Janeiro (1751-1808). Rio de Janeiro: Renovar, 2004, p. 565. 
incerto; a segunda, suppondo à existencia do delicto, só se occupava com a indagação do agressor" 28 .

\section{A) DeVASSAS EsPeCIAIS}

As devassas especiais ${ }^{29}$ eram tiradas por um juízo ordinário de forma obrigatória, pelo dever do cargo ${ }^{30}$ nos casos:

Sobre as mortes, forças de mulheres, que se queixarem, que dormiram com ellas carnalmente per força, fogos postos, e sobre fugida de presos, quebrantamento de cadea, moeda falsa, resistencia, offensa de Justiça, carcere privado, furto de valia de marco de prata $^{31}$ e dahi para cima ${ }^{32}$.

Nesses $\operatorname{casos}^{33}$, existindo a materialidade do crime, o juízo deveria investigar em ex officio, mas também poderia atender a requisição de particular nos casos de furtos menores, desde que não fosse inferior a quantia de duzentos réis. Nos casos de requisição, a parte deveria jurar ao evangelho que estava relatando fatos verdadeiros e apresentar até oito testemunhas ${ }^{34}$.

Assim, a devassa especial possuía um local certo onde o crime era cometido, contudo seu autor era desconhecido. A competência para

28 Idem.

29 Para estudar os casos de devassa especial ver: ORDENAÇÕES FILIPINAS Livro I, Título LXV, parágrafo 31 e seguintes.

30 Ver: LEMOS, Carmem Silvia. A justiça local: os juízes ordinários e as devassas da Comarca de Vila Rica (1750-1808). Dissertação (mestrado em história) Universidade Federal de Minas Gerais, Belo Horizonte, 2003. e PRECIOSO, Daniel. Absolvida pela loucura: a mulata Rita e o furto dos brincos de uma imagem sagrada (Vila Rica, 1760). Temporalidades, v. 2, p. 110-119, 2010.

31 Um de prata amoedado valia aproximadamente $1 \$ 500$ réis (PUNTONI, Pedro. Da libra ao real: sobre a formação do sistema monetário português (11851580). Revista de História. São Paulo, n. 178, p. 1-38, 2019). ORDENAÇÕES FILIPINAS, Livro I.

O rol de casos em que as devassas especiais eram permitidas era muito extenso, para se aprofundar ver: PEREIRA e SOUSA, Joaquim Jose Caetano. Primeiras linhas sobre o processo criminal. $3^{\mathrm{a}}$ ed. Lisboa: Typo. Rollandiana, 1820 , p. 25 e seguintes. 
tirá-la era do juízo do território onde o fato aconteceu, podendo este, em casos específicos, ser substituído por determinação real ${ }^{35}$ por um ministro de comissão ${ }^{36}$.

Segundo Pierangelli ${ }^{37}$, o prazo para iniciá-la era, com exceção dos casos de flagrante ${ }^{38}$ e de incêndio ${ }^{39}$, de até oito dias contados a partir do conhecimento por parte do juízo, e o prazo final para conclusão dos trabalhos era de trinta dias depois do delito cometido ${ }^{40}$.

\section{B) Devassas Gerals}

Diferente das especiais, as devassas gerais ${ }^{41}$ eram vedadas pelas Ordenações Filipinas ${ }^{42}$, podendo ser efetuada somente nos casos de correição $0^{43}$. Eram tiradas a cada ano ${ }^{44}$ ou em tempo certo e determinado ${ }^{45}$ sobre delitos incertos, seguindo esta regra:

35 SALGADO, Karine. O Direito no Brasil Colônia à Luz da Inconfidência Mineira. Revista Brasileira de Estudos Políticos, v. 98, p. 479-494, 1 jul. 2008, p. 487.

36 PEREIRA e SOUSA, Joaquim Jose Caetano. Primeiras linhas sobre o processo criminal. $3^{\text {a }}$ ed. Lisboa: Typo. Rollandiana, 1820, p. 30.

37 PIERANGELLI, José Henrique. Processo Penal: evolução histórica e fontes legislativas. Bauru: Jalovi, 1983, p. 65.

38 Nesse caso deveria começar no mesmo dia da prisão. Ver: ORDENAÇÕES FILIPINAS, Livro I, Título LXV, parágrafo 37.

39 Nesse caso deveria começar no dia em o fogo foi apagado, ou no máximo no dia seguinte e terminar dentro de quinze dias. Cf: ORDENAÇÕES FILIPINAS, Livro V, Título LXXXVI, parágrafo 2.

40 , PEREIRA e SOUSA, Joaquim Jose Caetano. Primeiras linhas sobre o processo criminal. $3^{\mathrm{a}}$ ed. Lisboa: Typo. Rollandiana, 1820, p. 26.

${ }^{41}$ Para estudar os casos de devassa geral ver: ORDENAÇÕES FILIPINAS, Livro I, Título LXV, parágrafo 39 e seguintes.

42 Ver: ORDENAÇÕES FILIPINAS, Livro I, Título LXV, parágrafo 31: Por se evitarem os inconvenientes, que contra serviço de Deus e nosso se seguiriam de se tirarem devassas geraes, mandamos a todas as Justiças, que as não tirem.

43 MARTINS, Lucas Moraes. Uma genealogia das devassas na história do Brasil. In: XIX Congresso Nacional do CONPEDI, 2010, Fortaleza. Anais do XIX Congresso Nacional do CONPEDI. Fortaleza: Fundação Boiteux, 2010, p. 6042

${ }^{44}$ Ver: ORDENAÇÕES FILIPINAS, Livro I, Título LXV, parágrafo 72.

45 PEREIRA e SOUSA, Joaquim Jose Caetano. Primeiras linhas sobre o processo criminal. $3^{\text {a }}$ ed. Lisboa: Typo. Rollandiana, 1820, p. 22. 
a todos os Juizes das cidades, villas e lugares de nossos Reinos e Senhorios, que do dia, que começarem à servir seus Officios, a dez dias primeiros seguintes, comecem tirar inquirições devassas sobre os Juizes que ante eles foram, a qual acabarão de tirar até trinta dias do dia, que for começada: e nella sejam perguntadas ao menos até trinta testemunhas per os capitulos que se seguem, que mais razão tenham de saber delles ${ }^{46}$.

Deste modo, eram competentes para tirar a devassa geral os juízos ordinários, juízos de fora, e corregedores ${ }^{47}$. Em casos excepcionais o corregedor geral podia efetuar uma devassa sobre a jurisdição dos juízos de fora e ordinários. Também era permitido em casos extraordinários, através de decretos reais, realizar no Brasil colônia devassas gerais para apurar casos que não eram regulados pelas Ordenações Filipinas, mas que eram de interesse da administração real ${ }^{48}$.

Assim, as devassas só poderiam ser tiradas nos casos previstos na lei ${ }^{49}$, sendo nulas caso fossem efetivadas fora do expresso na legislação com pena de banimento e multa para o juiz ${ }^{50}$. Esta regra era clara, porém,

houve clara polissemia do conceito de devassa ao longo dos séculos e nem nas Ordenações o termo é isento de flutuações. Estas, no Livro I, título 65 a definem como investigação de delitos por iniciativa de juízes ou ordem real. Em geral tanto as Ordenações como as leis extravagantes consideram-nas aplicáveis em todos os crimes de natureza pública, no desempenho dos ofícios públicos e em crimes particulares mais graves. No período pombalino muitas devassas

46 ORDENAÇÕES FILIPINAS, Livro I, Título LXV, parágrafo 39.

47 SALGADO, Karine. O Direito no Brasil Colônia à Luz da Inconfidência Mineira. Revista Brasileira de Estudos Políticos, v. 98, p. 479-494, 1 jul. 2008, p. 487

48 Ver: PIERANGELLI, José Henrique. Processo Penal: evolução histórica e fontes legislativas. Bauru: Jalovi, 1983; ALMEIDA JUNIOR, João Mendes de. Processo criminal brasileiro. Volume I. 4. ${ }^{a}$ ed. São Paulo: Freitas Bastos, 1959; e MARTINS, Lucas Moraes. Uma genealogia das devassas na história do Brasil. In: XIX Congresso Nacional do CONPEDI, 2010, Fortaleza. Anais do XIX Congresso Nacional do CONPEDI. Fortaleza: Fundação Boiteux, 2010.

49 PEREIRA e SOUSA, Joaquim Jose Caetano. Esboço de hum diccionario juridico, theoretico, e practico: remissivo às leis compiladas, e extravagantes. Lisboa: Typographia Rollandiana, 1825, p. 21.

ORDENAÇÕES FILIPINAS, Livro I, Título LXV, parágrafo 68. 
foram instituídas por provisão real, ampliando-se o poder do juiz, que ficou autorizado a prender o acusado por simples indício ${ }^{51}$.

As devassas foram assim utilizadas para atender aos interesses da administração colonial. No que se refere ao prazo, a conclusão dos trabalhos deveria ser de trinta dias contados a partir do início da investigação ${ }^{52}$. O pagamento das devassas era feito pelas pessoas acusadas e, não havendo culpado/a, pelo/a requerente ${ }^{53}$, conforme determinava as Ordenações ${ }^{54}$.

O juízo poderia convocar para a devassa geral e também para especial, por regra, um número máximo de trinta testemunhas, sendo exceçãoos casos de incêndio, furto de pequena quantidade, dano em horta ou pomar e fogos com pólvora, podendo variar de oito a vinte testemunhas no máximo dependendo do evento ${ }^{55}$.

Por regra, as devassas eram nulas quando não precedida de denúncia, não expresso a causa, o lugar e o tempo do delito, não tirada ou concluída dentro de termo legal, não se preencheu o número de testemunhas, não foi tirada em caso expresso em lei, quando as testemunhas não eram perguntadas pelo próprio juiz, se o juiz era incompetente ou inimigo do réu ou se o escrivão era suspeito ${ }^{56} \mathrm{e}$, especificamente, quando não constava o exame de corpo de delito ${ }^{57}$.

51 WEHLING, Arno; WEHLING, Maria José. Direito e Justiça no Brasil Colonial O Tribunal da Relação do Rio de Janeiro (1751-1808). Rio de Janeiro: Renovar, 2004, p. 562.

52 Ver: ORDENAÇÕES FILIPINAS, Livro I, Título LXV, parágrafo 39.

53 WEHLING, Arno; WEHLING, Maria José. Direito e Justiça no Brasil Colonial O Tribunal da Relação do Rio de Janeiro (1751-1808). Rio de Janeiro: Renovar, 2004, p. 562.

54 Ver: ORDENAÇÕES FILIPINAS, Livro I, Título LXV, parágrafo 34.

55 Para analisar cada um desses casos, ver: PEREIRA e SOUSA, Joaquim Jose Caetano. Esboço de hum diccionario juridico, theoretico, e practico: remissivo às leis compiladas, e extravagantes. Lisboa: Typographia Rollandiana, 1825, p. 28.

56 PEREIRA e SOUSA, Joaquim Jose Caetano. Esboço de hum diccionario juridico, theoretico, e practico: remissivo às leis compiladas, e extravagantes. Lisboa: Typographia Rollandiana, 1825, p. 32-34.

57 Corpo de delito era entendido como "a existência de um crime que se manifesta de maneira que não se pode duvidar que ele fosse cometido. Ele é a base de todo o procedimento criminal, sem o qual este não subsiste. É de indispensável e não pode ser suprimido pela confissão do acusado. Forma-se o corpo 
O corpo de delito se caracterizava como um elemento essencial no procedimento da devassa e no processo criminal. Sabemos que a concepção de processo criminal que se desenvolve no direito real português durante as idades média e moderna está vinculada ao "resgate" do direito de Justiniano na idade média, integrado às fontes de direito da maioria dos reinos europeus e também ao trabalho doutrinário, realizado pelos juristas após o século XII ${ }^{58}$, que culminou com o desenvolvimento do Ius Commune ${ }^{59}$.

Hespanha nos recorda que apesar de as Ordenações do Reino de Portugal conferirem ao direito romano um lugar subsidiário no quadro das fontes do direito real, na prática, era ele aplicado como fonte principal $^{60}$. Além disso, a força do direito comum, em face dos Iura Propria

de delito pela inspeção ocular, por conjecturas legítimas, pelos depoimentos das testemunhas" (PEREIRA e SOUSA, Joaquim Jose Caetano. Esboço de hum diccionario juridico, theoretico, e practico: remissivo às leis compiladas, e extravagantes. Lisboa: Typographia Rollandiana, 1825, p. 51).

GIULIANI, Alessandro. Il concetto di prova. Contributo alla logica giuridica. Milano: Giuffrè, 1961, p. 187, p. 231 e ss.; MARCHETTI, Paolo. Testis contra se. L'imputato come fonte di prova nel processo penale dell'età moderna. Milano: Giuffrè, 1994, p. 34; SCHMOECKEL, Mathias. Humanität uns Staatsräson. Die Abschaffung der Folter in Europa und die Entwicklung des gemeinen Strafprozeß- und Beweisrechts seit dem hohen Mittelalter. Köln: Böhlau, 2000, p. 188. LÉVY, Jean Philippe. La hiérarchie des preuves dans le droit savant du Moyen-Âge depuis la renaissance du droit romain jusqu'à la fin du XIVe siècle. Paris: Sirey, 1939, p. 1939.

Sobre as dificuldades de definição do Ius commune, entre outros, ver: CLAVERO, Bartolomé. História del derecho: derecho común. Salamanca: Universidad de Salamanca, 1994, p. 24 e ss.

O autor nos apresenta que os juristas estudavam direito romano, a doutrina divulgava seus trabalhos e os tribunais os aceitavam. Dessa maneira foi se formando o que Hespanha denomina de "um costume doutrinal e judicial contra legem, mas dotado de verdadeira opinio iuris". O autor nos apresenta que Dom João I (1426) através de lei ordena a tradução de uma parte do Código Justiniano, com a glosa de Arcúsio e com os comentários de Bartolo de Sassoferrato. Ademais, nas Ordenações Filipinas, livro II, no título LXIV, núm. 1 se situa a importância da "comum opinião dos doutores" e faz também referência a que "se guarde a opinião de Bartolo" (HESPANHA, Antonio. História das Instituições - Época medieval e moderna. Coimbra: Editora Almedina, 1982. p.442 e ss.). Sobre a formação e expansão do direito comum na Europa, ver, dentre outros: GILISSEN, John. Introdução histórica ao direito. Lisboa: Fundação Calouste Gulbenkina, 1979, p. 202 e ss., p. 350 e ss. Para uma análise 
era desigual, justamente porque "a maior parte do corpo do direito era constituído por direito comum, contendo o direito próprio apenas algumas especialidades particulares a cada Reino"61.

De todas as formas, especificamente na esfera processual penal, a força do direito próprio parece ter se sobreposto ao do direito comum. Segundo nosso autor, existe uma ruptura com o discurso do Ius Commune quando se trata do processo criminal. Uma característica dos processos cíveis do direito comum, por exemplo, é adotada na esfera penal: a recorrência às testemunhas. Isto foi identificado nos processos que manuseamos e, em todos os casos, os testemunhos foram considerados elementos centrais no procedimento de investigação.

Os doutrinadores portugueses fazem referência à importância do testemunho. Ao comentar "Decisiones" do Reino de Portugal, em obra datada do ano de 1609, Alvaro Valasco, sustenta: "Probatio per testes admittitur in quacunque quantitate de Iure Regio" ${ }^{2}$. Ocorre que a orientação do direito comum era a admissão de dois testemunhos oculares de boa fama como prova plena na esfera criminal. Nem mesmo quando ocorre a flexibilização das provas legais, com a introdução da pena extraordinária, chega a se alterar esse entendimento, que implicava optar por focar o processo muito mais na força da confissão judicial, a "rainha das provas"63.

sobre a recepção do direito comum em Portugal e a questão das fontes do direito, ver, dentre outros, CRUZ, Guilherme Braga da. O direito subsidiário na história do direito português. Revista Portuguesa de História, Coimbra, n. 14, p. 177-316, 1974.

${ }^{61}$ HESPANHA, Antonio. Direito moderno e intertextualidade: direito próprio e direito comum em «De Jure Lusitano» (1645), de Mateus Homem Leitão. In: RIBEIRO, Maria Manuela Tavares (org.). Outros combates pela história. Coimbra: Imprensa da Universidade de Coimbra, 2010, p. 443.

62 VALASCO, Alvaro. Decisionum Consullationum Acrerum iudicatarum in Regno Lusitanae. Venetiis: Bernardum Iutam, Ioan. Bapt. Cioottum \& Socios, 1609, consultatio XXI, n. 10, p. 112.

${ }_{63}$ Conforme sustenta Hespanha: “(...) na verdade, a prática de averiguar, formalmente, ouvindo testemunhas e procurando oficiosamente reunir provas, de actividades criminosas não especificadas, era algo de muito estranho num sistema jurídico em que o direito penal ainda se baseava, sobretudo, na acusação de parte, remetendo o juiz para o papel de destinatário dos resultados de um esforço probatório que se entendia caber essencialmente aos ofendidos" (HESPANHA, Antonio. Direito moderno e intertextualidade: direito próprio e direito comum em «De Jure Lusitano» (1645), de Mateus Homem Leitão. 
Ao analisar a obra de Leitão, Hespanha ${ }^{64}$ nos diz que o direito português também "teria sido menos exigente" do que o direito comum no que tange aos requisitos que autorizam o emprego de uma inquirição. A existência de vestígios ou simples indícios são incorporados ao conceito de corpo de delito no reino de Portugal.

O corpo de delito, que era um pré-requisito para abertura de uma investigação criminal, muito estudado pela doutrina do Ius Commune (que desenvolve uma sofisticada teoria abarcando inclusive os crimes que não deixam vestígios), receberia um tratamento muito diverso no reino de Portugal, prevalecendo a concepção lusitana. Como consequência, recorda Hespanha, se conferia mais poder inquisitório ao magistrado, tanto nas devassas gerais como nas especiais.

Segundo Almeida Junior ${ }^{65}$, as devassas tanto especiais como gerais eram tiradas sem que a parte acusada pudesse fazer qualquer intervenção e constavam na fase inicial de um processo acusatório de qualquer ação criminal ${ }^{66}$, o qual poderia se iniciar de três formas. A primeira era a partir de uma denúncia ${ }^{67}$ originada em caso das ofensas públicas por

In: RIBEIRO, Maria Manuela Tavares (org.). Outros combates pela história. Coimbra: Imprensa da Universidade de Coimbra, 2010, p. 478).

HESPANHA, Antonio. Direito moderno e intertextualidade: direito próprio e direito comum em «De Jure Lusitano» (1645), de Mateus Homem Leitão. In: RIBEIRO, Maria Manuela Tavares (org.). Outros combates pela história. Coimbra: Imprensa da Universidade de Coimbra, 2010, p. 479.

65 ALMEIDA JUNIOR, João Mendes de. Processo criminal brasileiro. Volume I. 4. ${ }^{\mathrm{a}}$ ed. São Paulo: Freitas Bastos, 1959, p. 134.

${ }^{66}$ FREIRE, Pascoal José de Melo. Instituições de direito criminal português. Tradução de Miguel Pinto de Menezes. Boletim do Ministério da Justiça, n. 155-156, Lisboa, Ministério da Justiça, 1966, p. 82 e WEHLING, Arno; WEHLING, Maria José. Direito e Justiça no Brasil Colonial - O Tribunal da Relação do Rio de Janeiro (1751-1808). Rio de Janeiro: Renovar, 2004, p. 564.

67 A denúncia é a declaração de crime público feita em juízo para se proceder contra o delinquente por ofício de justiça (PEREIRA e SOUSA, Joaquim Jose Caetano. Primeiras linhas sobre o processo criminal. $3^{\mathrm{a}}$ ed. Lisboa: Typo. Rollandiana, 1820, p. 47-51). Divide-se em pública, quando o delator diz o seu nome, ou oculta, no caso contrário; em jurada ou simples; e em voluntária, quando a faz de livre vontade, ou necessária, quando a faz por mandado da lei (FREIRE, Pascoal José de Melo. Instituições de direito criminal português. Tradução de Miguel Pinto de Menezes. Boletim do Ministério da Justiça, n. 155-156, Lisboa, Ministério da Justiça, 1966, p. 100). 
qualquer pessoa ou no caso das ofensas particulares pelo ofendido eram muitas vezes feitas de maneira secreta. A segunda era através de uma acusação realizada através do auto de querela ${ }^{68}$ e a terceira se iniciava através das inquirições ${ }^{69}$.

\subsection{INQUIRIÇÕES DEVASSAS NA SOCIEDADE COLONIAL DO BRASIL}

As devassas eram instrumentos de poder e informação caracterizando-se como um modelo de investigação desproporcional e autoritário, todavia coerente com a organização da sociedade brasileira no período colonial.

A institucionalização do poder português no Brasil com sua administração e regras não esteve atrelada à formação e desenvolvimento de uma base social correspondente. Caracterizou-se mais por uma imposição ideológica e social que não permitiu que a sociedade colonial tivesse tempo e maturidade de formar suas próprias instituições. Assim,

68 Queréla: queixa de aggravo, injuria, contestação jurídica; causa, demanda. « defendian justa-. Chron. de D. João 1. » (ant.) queixa. Ter de - poderosos, motivo de queixa (FARIA, Eduardo. Novo dicionário da língua portuguesa. $4^{\mathrm{a}}$ Ed. v. 2. Rio de Janeiro: Typographia Imperial e Constitucional, 1859b. p. 1015). Foram reguladas pelas Ordenações Filipinas Livro V, Título CXVII: Em que casos se devem receber querelas e Titulo CXVIII: Dos que querelam maliciosamente, ou não provam suas querelas, e denunciações. Para fazer a querela perfeita não bastava a simples denuncia, o Quereloso deveria prestar juramento ao Evangelho, nomear as testemunhas indicando claramente o local de residência das mesmas e assinar juntamente com o juiz a queixa conforme: ORDENAÇÕES FILIPINAS Livro V, Título CXVII, parágrafo 8. O prazo para a querela ocorrer é de um ano, depois do caso acontecido e as testemunhas arroladas devem se apresentar dentro de vinte dias contados do dia em que a mesma foi dada. Para aprofundar, ver: PEREIRA e SOUSA, Joaquim Jose Caetano. Primeiras linhas sobre o processo criminal. $3^{\mathrm{a}}$ ed. Lisboa: Typo. Rollandiana, 1820, p. 34-46 e FREIRE, Pascoal José de Melo. Instituições de direito criminal português. Tradução de Miguel Pinto de Menezes. Boletim do Ministério da Justiça, n. 155-156, Lisboa, Ministério da Justiça, 1966, p. 88-92.

69 PIERANGELLI, José Henrique. Processo Penal: evolução histórica e fontes legislativas. Bauru: Jalovi, 1983, p. 56; FERNANDES, Antonio Scarance. Teoria Geral do Procedimento e o Procedimento no Processo Penal. São Paulo: RT, 2005, p. 115; e FREIRE, Pascoal José de Melo. Instituições de direito criminal português. Tradução de Miguel Pinto de Menezes. Boletim do Ministério da Justiça, n. 155-156, Lisboa, Ministério da Justiça, 1966, p. 82. 
a política criminal portuguesa aplicada à realidade da colônia ocorreu a partir dos interesses da metrópole em choque com a realidade local ${ }^{70}$.

No caso específico das devassas especiais, o objetivo era manter a ordem social do lugar sendo efetivadas contra pessoas pobres, principalmente pretos e pardos. Já no caso das devassas gerais, estas tinham como objetivo o domínio dos magistrados garantindo o controle sobre aqueles que exerciam o poder em nome da Coroa $^{71}$. Dessa forma, as devassas serviam como uma ferramenta institucionalizada para garantir acesso à informação e realizar intervenções necessárias para a manutenção do aparelho colonial segundo as determinações da metrópole portuguesa.

As devassas originadas no direito português adquiriram no Brasil condições e características próprias ${ }^{72}$ tanto na sua aplicação especial como na geral. Para atender o objetivo de controlar da administração colonial e considerar as especificidades de cada local, identificamos a relativização de diferentes requisitos como a limitação do número máximo de 30 testemunhas e a exigência do exame de corpo de delito.

Ao estudar autos de devassa sobre descaminho do ouro e diamantes na capitania de Minas Gerais, Santos ${ }^{73}$ discorre que para compreender a aplicação da justiça nos casos envolvendo as devassas é fundamental a análise dos autos, pois serão apresentadas características particulares sobre o tempo em que foram tiradas.

O que a pesquisadora nos aponta é que a sociedade era marcada por uma forte hierarquização social que se reflete na aplicação da justiça.

70 RIBEIRO, Ludmila Mendonça; DUARTE, Thais Lemos. Do processo penal colonial a reforma processual penal de 2008: análise sócio-histórica do Sistema de Justiça Criminal brasileiro. Interseções - revista de estudos interdisciplinares, v. 13, n. 1, p. 40-64, 2011, p. 44.

${ }^{71}$ MARTINS, Lucas Moraes. Uma genealogia das devassas na história do Brasil. In: XIX Congresso Nacional do CONPEDI, 2010, Fortaleza. Anais do XIX Congresso Nacional do CONPEDI. Fortaleza: Fundação Boiteux, 2010, p. 6043.

72 MARTINS, Lucas Moraes. Uma genealogia das devassas na história do Brasil. In: XIX Congresso Nacional do CONPEDI, 2010, Fortaleza. Anais do XIX Congresso Nacional do CONPEDI. Fortaleza: Fundação Boiteux, 2010, p. 6048.

73 SANTOS, Edenir Vitória de Araujo. Auto de Devassa do crime de descaminho e contrabando: o inquérito, a verdade e os sujeitos históricos nos jogos do poder (Minas Gerais, Brasil, 1792). In: V Colóquio Nacional Michel Foucault: a arte neoliberal de governar e a educação. Uberlândia: EdUFU, 2017, p. 11. 
O tratamento dado a um fazendeiro/a é infinitamente diferente do escravizado/a, sendo o constrangimento e a pressão sobre a pessoa acusada de um crime maior na intensidade que sua posição social diminui.

Cientes de que o que está escrito nos autos é reflexo de uma sociedade hierarquizada e desigual e que muitos testemunhos são uma "verdade" construída para atender aos interesses de grupos poderosos, pretendemos agora mergulhar na análise e apresentação de dados sobre os autos de devassa disponíveis para consulta no Arquivo Público do Estado da Bahia (APEB) nas seções colonial e judiciária.

\section{Os casos da região do Recôncavo Baiano}

Selecionamos para apresentação de dados um total de 89 documentos relacionados à investigação de delitos oriundos da região do Recôncavo Baiano ${ }^{74}$. Estes estão distribuídos entre os séculos XVIII e a primeira metade do século XIX, no intervalo entre os anos de 1712 e 1832.

É fundamental registrar a dificuldade de acesso e interpretação desses processos que, por serem fontes primárias com mais de dois séculos encontram-se, muitas vezes, deteriorados. Em nosso caso, dos 89 processos, $44 \%$ estão conservados, os outros 56\% estão parcialmente deteriorados, sendo que $4 \%$ destes estão ilegíveis ou completamente deteriorados.

Outro problema que enfrentamos é adentrar na lógica de funcionamento de cada caso. Conservados ou não, eles são únicos e representam uma história que só faz sentido se for interpretada a partir da ótica da sociedade que a produziu. Os personagens descritos eram pessoas reais, na grande maioria dos casos pessoas pobres. Ao analisar cenários como esse, Foucault ${ }^{75}$ denomina estas pessoas de "vidas infames", pois não possuíram glórias ou foram premiadas em seu tempo, mas ganharam uma pequena notoriedade ao se chocarem com a estrutura de poder.

74 Processos distribuídos espacialmente conforme apresentado e disponíveis para consulta no Arquivo Público do Estado da Bahia (APEB) encontrados na seção judiciária.

75 FOUCAULT, Michel. A vida dos homens infames. In: FOUCAULT, Michel. Estratégia, poder-saber. Ditos e escritos IV. Rio de Janeiro: Forense Universitária, 2003, p. 209. 
A vida dessas pessoas e seu cotidiano emergem do passado como uma rica fonte de pesquisa justamente a partir da repressão que sofreram. Suas vidas serão narradas além do tempo em que viveram, porque, ainda que brevemente, suas histórias foram minimamente narradas nas folhas dos autos de delito. Segundo Agamben ${ }^{76}$, essas pessoas tiveram um brilho momentâneo, aparecendo unicamente na história por meio de processos judiciais que visavam sua punição.

Acreditamos assim que dar visibilidade às informações e aos dados presentes nesses documentos significa apresentar uma parte esquecida de nossa história. Todos os elementos, a contar a própria existência, que compõe esses documentos são dados valiosíssimos que precisam ser descortinados.

\subsection{Dados GERAIS SOBRE A ORIGEM DOS PROCESSOS PENAIS}

Analisando a origem dos processos selecionados identificamos que uma minoria dos casos não se iniciou como devassa ou querela. Observamos dois casos no século XVIII. O primeiro no ano de $1780^{77} \mathrm{e}$ o segundo no ano de $1786^{78}$, ambos ocorridos na cidade de Cachoeira e intitulados de libelo de crime civil ${ }^{79}$.

76 AGAMBEN, Giorgio. Profanações. Tradução de Selvino Assmann. São Paulo: Boitempo Editorial, 2007, p. 52.

77 APEB, seção judiciária, maço s/nº, doc. s/no fls: 07.

78 APEB, seção judiciária, maço 1382, doc. nº 10.

79 O libelo crime era a parte principal e inicial do processo ordinário (TEIXEIRA, Maria Lúcia Resende Chaves. As cartas de seguro: de Portugal para o Brasil colônia - O perdão e a punição nos processos-crimes das Minas do Ouro (1769-1831). Tese (Doutorado em História Social) - Faculdade de Filosofia, Letras e Ciências Humanas, Universidade de São Paulo. São Paulo. 2011, p. 45). Sobre os libelos, salientamos que foram escritos estudos de doutrina voltados para a prática judicial. Dentre estes, citamos uma obra que foi publicada por Gregorio Martins Caminha, ainda no século XVI, e que posteriormente foi objeto de revisão por João de Matos. Este último introduz apenas modelos de peças processuais, mas não realiza comentários relevantes sobre a matéria. Ver COSTA, João Martin. Tractado das formas dos libellos, das alegações judiciaes, do processo do Juizo Secular, do ecclesiatico, e dos contratos com suas glosas do Licenciado Gregorio Martins Caminha, reformado de novo com addiccoes e annotacoes copiosas. Officina dos irmãos, e sobrinho 
Identificamos mais três ${ }^{80}$ casos ocorridos no século XIX. Nos três casos os processos foram denominados como Sumário Ex Officio, sendo determinados por juízes de fora para investigar um suposto homicídio, um caso de porte ilegal de fogo e furto e uma tentativa de homicídio, respectivamente.

Os casos que se iniciavam através de querela foram mais numerosos, totalizando 23 ocorrências em nosso recorte espaço-temporal, 5 destas foram registradas no século XVIII e 18 nos primeiros trinta anos do século XIX. Segundo Freire ${ }^{81}$, querela era um modo de investigar e perseguir os crimes a partir de uma delação juramentada feita ao juízo competente seja de crime público ou particular.

Conforme apresentado, o juramento era uma exigência formal para esses casos, porém, em nossa investigação percebemos que, na maioria dos processos em que constava a querela, o juramento por escrito não foi realizado. Nos cinco casos encontrados no século XVIII, apenas em um deles constava o juramento. Já nos casos estudados do século XIX, apenas sete casos constavam o juramento por escrito caracterizando-se como querelas perfeitas.

Em todos os outros casos onde a querela foi realizada, a forma foi imperfeita, se assemelhando à denúncia, ou seja, a simples delação de um crime. Esta abria caminho para a inquirição, contudo não era necessário jurar e não era obrigatório pagar as custas ${ }^{82}$.

Estes fatores podem ter sido fundamentais para que os denunciantes não conseguissem concretizar a querela em sua forma perfeita. $\mathrm{O}$ fato dos autores das denúncias serem pessoas pobres e sem recursos pode

Ginioux, Impressores do Santo Oficio, 1764. Sobre a forma de aplicar os libelos no Reino de Portugal, p. 84 e ss.

80 Casos ocorridos em 1813 (APEB, seção Judiciária, maço 1625, S/nº ), 1820 (APEB, seção Judiciária, maço 4416, doc. 1) e 1821 (APEB, seção Judiciária, maço 4330, doc. 01).

81 FREIRE, Pascoal José de Melo. Instituições de direito criminal português. Tradução de Miguel Pinto de Menezes. Boletim do Ministério da Justiça, n. 155-156, Lisboa, Ministério da Justiça, 1966, p. 88.

82 FREIRE, Pascoal José de Melo. Instituições de direito criminal português. Tradução de Miguel Pinto de Menezes. Boletim do Ministério da Justiça, n. 155-156, Lisboa, Ministério da Justiça, 1966, p. 100. 
ter influência direta na ausência de pagamento de custas e na capacidade de escrever ou assinar um juramento.

Mais da metade dos casos de querela envolviam escravizados ou ex-escravizados como vítima de crimes violentos, tais como lesões corporais ou raptos ${ }^{83}$. Como exemplo, temos um processo ${ }^{84}$ iniciado com querela em 7 de fevereiro de 1797 que evidencia bem este cenário. Na localidade de Cachoeira, foi investigado pelo Juiz Joaquim de Amorim Castro um crime de lesões corporais graves. Segundo consta, a vítima Jerônima da Silva Cerqueira, identificada como crioula forra, sofreu lesões corporais provocadas por Isabel, identificada como escrava de um homem chamado Pedro Ribeiro. A vítima alegou na querela estar lavando roupa em uma fonte no Arraial de São Pedro de Moretiba quando se iniciou uma discussão que resultou em uma briga com a ré, a qual fugiu retornando pouco tempo depois armada com uma navalha e ferindo-a.

O caso iniciado foi Agravo de Crime e não caracterizou a querela perfeita devido à falta de juramento e de pagamento das custas. Houve exame de corpo de delito, seguido do depoimento da vítima e requerimento pedindo uma carta de ré segura ${ }^{85}$, mas não consta convocação de testemunhas e não houve termo de conclusão ou de pronúncia para que possamos saber o resultado das investigações.

Outro cenário possível para a ausência do juramento era o uso dos termos querela e denúncia como similares e a não exigência da

83 Dos casos estudados, 50\% foram crimes de lesões corporais, $21 \%$ crimes de rapto de escravos, os outros $29 \%$ foram divididos entre furto de gado, calúnias, porte ilegal de armas, arrombamento, furto e corte e venda de madeira ilegal. APEB, seção Judiciária, maço 1625, doc. 05.

De importância para a prática social eram as cartas de seguro, por meio das quais a pessoa acusada poderia "livrar-se solto", isto é, responder ao processo em liberdade. A legislação determinava que as cartas de seguro tivessem validade por um ano, admitindo uma renovação por motivo justificado. As cartas de seguro poderiam ser confessativas, quando o réu admitia a responsabilidade do crime, ou negativas (WEHLING, Arno; WEHLING, Maria José. Direito e Justiça no Brasil Colonial - O Tribunal da Relação do Rio de Janeiro (1751-1808). Rio de Janeiro: Renovar, 2004, p. 565). 
formalidade em algumas localidades. Em um processo ${ }^{86}$ iniciado em 20 de março de 1771 na localidade de Itapicuru de Cima, investigado pelo Juiz Ordinário Lourenço Dias de Souza, o autor faz uma denúncia de assalto, que foi descrita no processo como querela, todavia sem definição de quem pagou as custas e sem juramento.

Na denúncia, José de Sousa Freire acusa um bando de homens, liderados por José de Souza Alvim, de assalto. Consta que o denunciante estava em seu sítio chamado Coralinho, quando foi assaltado pelo bando que era composto, segundo os depoimentos de quatro testemunhas, por Alvim, outro homem chamado Eugênio de Passos Pereira, dois índios e um negro, cujos nomes foram ignorados. O caso foi concluído em 7 de dezembro de 1772 e o termo de pronúncia considerou os acusados como culpados e determinou suas prisões.

Em ambos os casos as formalidades exigidas por lei não foram cumpridas em processos que se iniciaram com querela. Nos casos em que o processo era perfeito, as formalidades eram explícitas como evidencia o auto de querela registrado no ano de 1814, na localidade de Cachoeira. O procedimento ${ }^{87}$ foi conduzido pelo Juiz de Fora Francisco José de Freitas, tendo início em 17 de setembro do mesmo ano para investigar um crime de lesão corporal. Nos documentos apresentados e na análise do caso consta o translado da querela original registrada sob o mesmo número de maço do processo.

O registro foi feito para apurar a denúncia de João Nunes contra José Antonio Moreira da Silva. Segundo o autor, no dia 16 de agosto de 1814 , quando fazia uma ronda com o objetivo de desmanchar um acampamento utilizado para a prática de jogos ilegais, o réu o atacou com uma faca de ponta, o ferindo gravemente.

Este caso teve custas de "mil cento e vinte réis" e determinou a prisão preventiva do réu e sequestro de bens para pagamento de custas. No curso do procedimento foi iniciada uma devassa, precedendo o processo acusatório, para onde foram remetidos os autos desta querela, dando prosseguimento às investigações.

\footnotetext{
86 APEB, seção Colonial, maço 574, doc. S/No.

87 APEB, seção Judiciária, maço 5163, doc. 02.
} 


\subsection{As INQUIRIÇÕES DEVASSAS}

Casos como os relatados acima motivaram inquirições devassas, que durante o nosso recorte foram o principal instrumento de investigação, correspondendo a aproximadamente $70 \%$ dos casos estudados.

Conforme já apresentamos, as devassas se dividiam em gerais e especiais. As primeiras representam a minoria dos casos. Em todo nosso recorte, com 62 processos analisados, somente 2 foram originados como devassas gerais, ambos no século XVIII.

A primeira devassa geral data do ano de 1785 , se iniciando no mês de maio na localidade de Cachoeira, sendo conduzida pelo Juiz Gonçalves de Sena e requerida por Antonio José Pinto de Souza.

A inquirição ${ }^{88}$ foi feita contra Manoel Freire de Souza, administrador e responsável pelas obras da capela de Nossa Senhora da Conceição do Monte, na Vila de Nossa Senhora do Porto da Cachoeira.

Segundo consta, os moradores da localidade descontentes com a administração do requerido sob a capela e suas obras, buscam realizar a devassa para ter provas de má gestão e retirá-lo do cargo. Enfatizam que a mesma foi construída e mantida com dinheiro de esmolas do povo, em especial dos residentes da Rua do Pasto e não estava sendo bem administrada.

Em sua defesa, Manuel Freire de Souza argumenta que os moradores agiram com falsidade e má fé e com intuito de promover a desordem para retirá-lo do cargo. Na investigação não houve a inquirição de nenhuma testemunha, findando o caso em setembro do mesmo ano com a conclusão de que não se tratava de caso de devassa geral por lhe faltarem os requisitos para tal.

O principal requisito ${ }^{89}$ era que as devassas gerais só poderiam ser tiradas em caso de correição e sobre delitos incertos "sendo, pois, uma inquirição extraordinária, exorbitante, suspeita, e assaz perigosa, somente se deve tirar nos crimes mais graves e expressamente nomeados no direito" ${ }^{\circ}$.

\footnotetext{
88 APEB, seção Colonial, maço 611, doc. S/No.

89 Ver: ORDENAÇÕES FILIPINAS, Livro I, Título LXV.

90 FREIRE, Pascoal José de Melo. Instituições de direito criminal português. Tradução de Miguel Pinto de Menezes. Boletim do Ministério da Justiça, n. 155-156, Lisboa, Ministério da Justiça, 1966, p. 93.
} 
O entendimento no caso da capela de Nossa Senhora da Conceição do Monte foi de que este requisito não foi cumprido, não havendo termo de pronúncia e nem se determinando nenhuma prisão preventiva.

O segundo caso de devassa geral ocorreu no ano de 1796, se iniciando em 7 de janeiro de 1796 na localidade de Cachoeira sendo conduzida pelo Juiz de Fora Joaquim de Amorim Castro.

A inquirição ${ }^{91}$ foi requerida contra Nicolau de Oliveira, Antonio de Souza e outros. Segundo consta, tratava-se de um auto de devassa geral com o objetivo de investigar as decisões judiciais e as pessoas que cometeram delitos no ano de 1795.

Foram inquiridas para a realização dos trabalhos 43 pessoas. Todas apresentaram ocupação e eram residentes das vilas de Cachoeira, São Feliz e Muritiba, com idades entre 20 e 56 anos. Chamou-nos a atenção que nenhuma testemunha convocada foi classificada como negra, mas uma pessoa, sobre a qual não foi apresentada informação, está com o quesito cor em branco, porém nas declarações apresentadas foi enfatizado se tratar de crioulo forro.

A inquirição investigou delitos como falsidades em escrituras, se políticos se aproveitavam dos cargos ou deixavam de cumprir suas obrigações, se o carcereiro mantinha os presos em regime fechado, se havia pessoas que renegavam a Deus, além de casos de jogos ilegais, furtos, fraudes e qualquer outro delito público ou privado.

A inquirição teve seu termo de pronúncia em 12 de maio de 1796, apurando 25 casos ocorridos em 1795 e determinando a prisão preventiva dos dois réus citados e mais treze pessoas.

Este caso específico se caracteriza como o tipo de devassa conhecida como janeirinhas ${ }^{92}$. Estas eram tiradas por juízos de fora a cada ano para apurar delitos cometidos no ano anterior ${ }^{93}$.

Estes foram os únicos casos de devassas gerais encontradas em nosso recorte, todos os outros foram de inquirições especiais para analisar

\footnotetext{
91 APEB, seção Judiciária, maço 1327, doc. nº 27.

92 WEHLING, Arno; WEHLING, Maria José. Direito e Justiça no Brasil Colonial O Tribunal da Relação do Rio de Janeiro (1751-1808). Rio de Janeiro: Renovar, 2004, p. 60.

93 Ver: ORDENAÇÕES FILIPINAS, Livro I, Título LXV, parágrafo 71.
} 
delitos certos. Entre os 60 casos analisados, encontramos lesões corporais, invasões de domicílio, furtos, sedição, arrombamento de cadeia, fugas e homicídios.

Destacamos que aproximadamente $57 \%$ das inquirições analisadas foram tiradas para esclarecer casos de homicídio ou suspeita de homicídio, 33\% para investigar casos de lesão corporal e os outros 10\% para investigar crimes de fugas de presos e sedição. Nos chama a atenção o número de negros escravizados ou apresentados como forros elencados como vítimas nos crimes de lesão corporal ou morte. Dos 34 casos envolvendo assassinatos, temos como vítimas 20 pessoas negras e nos casos de lesões corporais de um total de 20 casos, 11 vítimas são pessoas negras.

Um desses casos envolvendo pessoas negras ocorreu em 13 de maio de 1822, na localidade de Cachoeira, onde sob a jurisdição do Juiz de Fora Antonio Cerqueira Lima foi investigado ${ }^{94}$ o homicídio de Catharina, escrava de um homem denominado Capitão José Paes Cardoso da Silva. Segundo consta, a escrava foi morta com 11 facadas por Miguel, escravo de um engenho pertencente ao desembargador Luiz Thomas Navarro de Campos.

A investigação chegou ao fim em 29 de maio de 1822 e o termo de pronúncia apontou Miguel como autor do delito, determinando a sua prisão preventiva. Para definir a autoria foi fundamental, conforme constam nos autos, a inquirição de trinta testemunhas e o exame de corpo de delito que apresentou os elementos que indicaram Miguel como autor do delito, dentre eles um pedaço de pano com sangue da vítima que estava na posse de Miguel.

O exame de corpo de delito era requisito necessário nos casos de devassa e querela. Este era realizado a partir dos vestígios deixados e analisados por inspeção ocular por médicos e cirurgiões. Segundo Freire ${ }^{95}$ :

em caso de homicídio, o cadáver e os ferimentos devem ser vistos por peritos e examinada a qualidade das armas, cicatrizes e envenenamento. No furto, há que investigar a qualidade, valor

94 APEB, seção Judiciária, maço 4251, doc. n 07, caixa nº 942.

95 FREIRE, Pascoal José de Melo. Instituições de direito criminal português. Tradução de Miguel Pinto de Menezes. Boletim do Ministério da Justiça, n. 155-156, Lisboa, Ministério da Justiça, 1966, p. 97. 
e designação das coisas roubadas, e se houve arrombamento de portas ou utilização de escadas. Nos delitos de factos transitórios, o corpo de delito forma-se de conjecturas, que se baseiem o mais possível na inspecção ocular, e do exame sumário de testemunhas, que deponham sobre o delito praticado. Por conseguinte, tudo o que possa demonstrar o malefício e sua qualidade e circunstâncias, deve ser investigado pelo juiz, antes de ele chegar inquirição especial.

O exame de corpo de delito era assim uma etapa fundamental das devassas e querelas, sendo determinante para apurar todas as circunstâncias em que um determinado delito ocorreu, como em um homicídio ocorrido em 1754, na localidade de Cachoeira.

Neste caso foi realizada uma devassa ${ }^{96}$ iniciada em 24 de dezembro de 1754, sob a jurisdição do Juiz de Fora Paschoal de Abrantes Madeira, onde a vítima Bento Vieira de Amorim, que exercia a profissão de alferes, foi assassinada com um tiro.

O exame de corpo de delito, conforme consta nos autos, foi fundamental para apurar que o autor do disparo foi Francisco Fernandes, que agiu a mando do seu irmão Antonio Pereira da Silva para se vingar pelo furto de um cavalo. Ambos eram filhos de Manuel Fernandes e primos da vítima.

Em outro caso, por exigência da realização do exame de corpo de delito, foi determinada a exumação de um cadáver. Ocorrido no ano de 1751, sob a jurisdição do Juiz Ordinário Fernando Cordeiro de Magalhães, o caso em questão tratava-se de uma morte cujas circunstâncias não foram esclarecidas.

Iniciou-se a devassa ${ }^{97}$ em 5 de novembro de 1751 para apurar as circunstâncias da morte de José Angola, escravo de Luiz Domingues Afonso. O Juiz do caso determinou a exumação do corpo para que fosse realizado o referido exame.

Foi constatado após exame que a causa da morte foi um defluxo sufocante provocado por garrotilho, doença causada por infecção viral e que provoca inchaço nas vias respiratórias superiores.

\footnotetext{
96 APEB, seção Judiciária, maço 1327, doc. nº 09, caixa nº 211.

97 APEB, seção Judiciária, maço 1327 , doc. nº 08.
} 
Apesar de ser um instrumento fundamental para apuração de delitos, e sua ausência representar a nulidade das devassas especiais, encontramos casos em que o exame de corpo de delito não foi realizado.

Apresentamos três casos em que este requisito foi dispensado, todos classificados como delitos de sedição. O primeiro foi realizado em Salvador, sendo a devassa ${ }^{98}$ iniciada em 14 de agosto de 1798 sob a jurisdição de Manoel de Magalhães Pinto Avelar de Barbedo, desembargador ouvidor geral do crime e intendente de polícia.

Foram investigados os réus Luiz Gonzaga das Virgens e Domingos da Silva Lisboa, ambos pardos forros, sobre a publicação de papéis que incitavam atos revolucionários e que apareceram em lugares públicos e igrejas na data de 12 de agosto de 1798 .

Foram ouvidas 69 testemunhas e o termo de pronúncia determinou a prisão de ambos. A prova utilizada para a prisão foi o fato de Luiz Gonzaga estar de posse dos referidos papéis.

O segundo caso ocorreu em 1817, também na cidade de Salvador, sob a jurisdição de Manoel José Batista Filgueiras, desembargador da Relação e Juiz da Inconfidência.

Em 22 de maio de 1817 se iniciou o auto da devassa da Inconfidência Pernambucana ${ }^{99}$. Esta foi aberta a partir de um pedido da Coroa em carta enviada por D. João VI para o Conde dos Arcos, Governador da Capitania da Bahia, dando ciência e pedindo providências acerca da insurreição em Pernambuco ${ }^{100}$.

98 APEB, seção Colonial, maço 581, doc. s/n ${ }^{\circ}$.

99 APEB, seção Colonial, maço 583-1.

${ }^{100}$ Os crimes da revolução pernambucana foram caracterizados pela coroa portuguesa como crimes exceptuados por se tratar de caso atroz que perturbou diretamente a ordem, o sossego público e a jurisdição Real, possuindo punição excepcional. Para aprofundar ver: CARNEIRO, Manoel Borges. Direito Civil de Portugal: I Das Pessoas, II Das Cousas, III Das Obrigações e Acções. Lisboa: Impressão Régia, 1826, p. 247; MELLO, Evaldo Cabral de. A outra independência (o federalismo pernambucano de 1817 a 1824). São Paulo: Editora 34, 2004; TAVARES, Francisco Muniz. História da revolução de Pernambuco em 1817. 3. ed. Recife: Imprensa Industrial, 1917; e CONTINENTINO, Marcelo Casseb. A Revolução Republicana de 1817: em busca de uma cultura constitucional brasileira. REJUR - Revista Jurídica da UFERSA, Mossoró, v. 1, n. 2, p. 57-67, ago./dez. 2017. 
A inquirição foi estabelecida sem limitação de tempo e nem de número de testemunhas para averiguar se existiam pessoas que estavam relacionadas aos "Rebeldes de Pernambuco" ou se deles recebiam papéis com ideais republicanos. A documentação desta devassa está incompleta, não sendo possível determinar o conteúdo dos termos de conclusão e pronúncia.

O terceiro caso foi registrado também no ano de 1817, na localidade de Pilão Arcado sob a jurisdição do Juiz Ordinário Capitão Dionízio Barreto Lima. Foram investigados na devassa ${ }^{101}$, iniciada em 06 de junho de 1817, Felix Suares e Manoel Ferreira Lima da Silva.

Foram inquiridas 30 testemunhas para se averiguar a correspondência de ambos com os "Rebeldes de Pernambuco" e identificar se mais pessoas possuíam ligação com o caso. Pelos testemunhos podemos identificar que ambos foram acusados por portar cartas recebidas de desconhecidos na localidade de Juazeiro. As testemunhas foram enfáticas em afirmar que ambos não possuíam nenhuma ligação com os fatos ocorridos em Pernambuco.

O termo de pronúncia de 18 de junho de 1817 desconsiderou este argumento e determinou a prisão preventiva dos dois investigados, bem como o sequestro de todos os seus bens para pagamento das custas.

O último processo de delito iniciado com devassa que se encontra disponível para análise em nosso recorte aconteceu no ano de 1832. Este só se tornou válido porque foi iniciado em 9 de novembro, dias antes de entrar em vigor o código de processo penal do Império de 29 de novembro de 1832 .

Este fazia parte de uma reforma da estrutura judiciária do Brasil e juntamente com o Código Penal de 1830 compunha a tentativa de formação de uma administração da justiça efetivamente nacional. As novas leis estavam em conformidade com os ideais iluministas e liberais já presentes na Constituição Imperial de 1824 e ofereciam garantias de defesa à pessoa acusada, caracterizando-se por extinguirem a possibilidade de inquirições devassas ${ }^{102}$.

\footnotetext{
${ }^{101}$ APEB, seção Colonial, maço 583-1.

102 RIBEIRO, Ludmila Mendonça; DUARTE, Thais Lemos. Do processo penal colonial a reforma processual penal de 2008: análise sócio-histórica do Sistema
} 
No caso em questão, ocorrido na localidade de Itapicuru de Cima, sob a jurisdição do Juiz Ordinário José Valentin dos Reis, foram ouvidas 30 testemunhas, juntamente com a realização de corpo de delito para se apurar a autoria da agressão sofrida por Sabino Pereira.

Os acusados eram índios da Vila, cujo único identificado era um indígena de nome Gonçalo. Foi determinada a prisão preventiva dos mesmos, porém no fim do processo foram soltos e considerados inocentes. Segundo os autos, o autor da devassa foi a Justiça, as custas foram pagas pelo cofre do município.

Esse caso, assim como os demais apresentados nesse trabalho, representam fontes riquíssimas de pesquisa para a compreensão dos institutos criminais de investigação no Brasil. Buscaremos avançar nas pesquisas de cada caso para colaborar com os estudos sobre as devassas e a história do processo penal brasileiro.

\section{Conclusão}

Os casos aqui estudados fazem parte da estrutura processual penal do Brasil colonial e se caracterizam como inquirições típicas da etapa inicial da investigação de crimes do direito português.

Foram aplicadas no Brasil principalmente a partir da vigência das Ordenações Filipinas, promulgadas no início do século XVII e possuíram vigência no Brasil até a entrada em vigor do código criminal e de processo criminal, já no período imperial.

Essas Ordenações regulamentavam o procedimento de Inquirição das Devassas, entendidas como o ato jurídico onde o juízo pode inquerir testemunhas para obter informações sobre determinado delito de forma silenciosa, podendo a parte investigada ser indiciada (pronúncia do réu) e presa preventivamente sem que seja ouvida previamente.

As devassas eram divididas em gerais e especiais. As primeiras eram tiradas em casos excepcionais e sobre delitos incertos. Já na segunda, o crime era conhecido e a investigação buscava o agressor. Se

de Justiça Criminal brasileiro. Interseções - revista de estudos interdisciplinares, v. 13 , n. 1 , p. $40-64,2011$, p. 47. 
caracterizavam como o instrumento de investigação de delitos no Brasil colônia. Deste modo, eram poderosas ferramentas para demonstrar o poder do Estado e obter informações.

As devassas estavam inseridas no contexto de imposição dos interesses da metrópole e das elites locais sobre a sociedade e visavam manter o controle da ordem social marcada pela exploração da mão de obra escravizada.

Identificamos que para atender os interesses do governo colonial as regras eram flexibilizadas em cada região, variando de caso para caso. Assim, dependendo da classe social da pessoa acusada, a aplicação da justiça seria diferenciada evidenciando uma sociedade altamente hierarquizada e desigual, onde testemunhos muitas vezes eram construídos para atender interesses de determinados grupos.

Para compreender melhor esse cenário, apresentamos os dados de 89 processos criminais iniciados na região do Recôncavo Baiano iniciados nos séculos XVIII e XIX, destes a grande maioria eram inquirições devassas.

Ao adentrar na lógica dos processos selecionados enfrentamos muitos desafios. A dificuldade de acesso e a sua interpretação é uma grande dificuldade, sobretudo quando a grande maioria dos documentos se encontra deteriorada. Em nosso recorte mais da metade dos documentos se encontravam deteriorados.

Outro grande desafio é a respeito da sociedade que produziu os documentos analisados. É imprescindível não julgar o passado e seus institutos com os olhos do presente, nos afastando da ideia de falsa continuidade e linearidade dos institutos jurídicos. Cada sociedade desenvolveu um conjunto de preceitos característicos calcados na cultura do período analisado e entrando para a História de maneira singular. A cultura é temporal, histórica. Ela influencia diretamente no convívio social e na produção de regras, variando de acordo com o contexto e possuindo especialidades locais ${ }^{103}$.

Observamos que a maioria dos processos selecionados se iniciou através de querelas ou devassas. No caso das querelas, identificamos que

${ }^{103}$ HESPANHA, Antonio. Cultura jurídica europeia: síntese de um milênio. Florianópolis: Fundação Boiteux, 2005, p. 27. 
a exigência formal de se prestar juramento para que se pudesse iniciar a investigação não foi cumprida na maioria dos casos. Em $65 \%$ dos documentos estudados as querelas foram realizadas na sua forma imperfeita, sendo comparadas à denúncia. Nesses casos, a investigação se iniciava com a simples delação de um crime e não era necessário pagar as custas do processo.

Esta ausência de cumprimento da forma pode ser explicada por duas possibilidades inerentes à própria lógica da sociedade. Primeiramente, o fato da maioria dos denunciantes serem pessoas pobres impossibilitava o juramento formal e o pagamento das taxas necessárias para se iniciar a querela e, por segundo, a utilização do termo querela como sinônimo da simples denúncia em algumas localidades da região.

Em alguns casos as querelas foram utilizadas para iniciar um processo de inquirição que daria origem a uma devassa, compreendida como um aprofundamento da investigação.

Identificamos que a maioria dos casos selecionados foi de devassas especiais. Somente dois casos foram registrados como devassas gerais. Desta forma, podemos concluir que a exigência formal de só iniciar o procedimento em casos extraordinários e graves era cumprida.

Já as devassas especiais visavam esclarecer delitos certos e que ocorriam em localidade específica. A grande maioria dos crimes investigados, cerca de $90 \%$, visava esclarecer crimes violentos, como homicídios e lesões corporais. O grande número desses casos investigados somado ao número de vítimas apresentadas nos documentos como pessoas negras escravizadas ou ex-escravizadas evidencia os conflitos sociais típicos de uma região em ebulição econômica e social marcada pela exploração da mão de obra escravizada ${ }^{104}$.

Observamos que a investigação desse e dos outros crimes relatados possuía no exame de corpo de delito um procedimento fundamental,

${ }^{104}$ A região possuía uma intensa efervescência social fruto das relações complexas que visavam garantir os interesses da grande lavoura com produção voltada para exportação, coexistindo com as lavouras destinadas a abastecer a economia interna e as necessidades oriundas do modelo escravocrata de produção (BARICKMAN, Bert. Um contraponto baiano: açúcar, fumo, mandioca e escravidão no Recôncavo, 1780-1860. São Paulo: Civilização Brasileira, 1998, p. 316). 
sendo este realizado em $85 \%$ dos casos estudados. Outro elemento típico a ser destacado era o número de testemunhas ouvidas nos casos de devassa. Em $87 \%$ dos casos foram convocadas 30 ou mais testemunhas para apoiar as investigações, evidenciando a importância dos depoimentos nos procedimentos investigativos em nosso recorte.

Apresentamos assim as inquirições devassas como um importante instrumento de investigação, que juntamente com as querelas e denúncias, compunham a primeira fase de investigação de delitos em nosso recorte. Os casos aqui apresentados, bem como os demais, são riquíssimos em informações sobre nosso passado jurídico e social e precisam ser mais bem estudados para que possamos ter um panorama mais próximo do contexto sociopolítico em que estavam inseridos. Cada um dos 89 processos merece uma análise profunda das circunstâncias em que foram produzidos, fato que será realizado em futuras pesquisas.

\section{REFERÊNCIAS}

ANDRÉ, André Luiz Pedro. As ordenações e o direito privado brasileiro. Revista Eletrônica da Faculdade de Direito de Campos, v. 3, p. 01-19, 2007.

AGAMBEN, Giorgio. Profanações. Tradução de Selvino Assmann. São Paulo: Boitempo Editorial, 2007.

ALMEIDA JUNIOR, João Mendes de. Processo criminal brasileiro. Volume I. $4 .^{\mathrm{a}}$ ed. São Paulo: Freitas Bastos, 1959.

BARICKMAN, Bert. Um contraponto baiano: açúcar, fumo, mandioca e escravidão no Recôncavo, 1780-1860. São Paulo: Civilização Brasileira, 1998.

CABRAL, Antonio Vanguerve. Pratica judicial, muyto util, e necessaria para os que principiaõ os officios de julgar, e advogar e para todos os que solicitaõ causas nos Auditorios de hum, e outro foro. Coimbra: Oficina de Antonio Simoes Ferreira, 1730. CARBASSE, Jean-Marie. Histoire du droit pènal et de la justice criminelle. Paris: PUF, 2000.

CARNEIRO, Manoel Borges. Direito Civil de Portugal: I Das Pessoas, II Das Cousas, III Das Obrigações e Acções. Lisboa: Impressão Régia, 1826.

CLAVERO, Bartolomé. História del derecho: derecho común. Salamanca: Universidad de Salamanca, 1994. 
COSTA, João Martin. Tractado das formas dos libellos, das alegações judiciaes, do processo do Juizo Secular, do ecclesiatico, e dos contratos com suas glosas do Licenciado Gregorio Martins Caminha, reformado de novo com addiccoes e annotacoes copiosas. Officina dos irmãos, e sobrinho Ginioux, Impressores do Santo Oficio, 1764.

CONTINENTINO, Marcelo Casseb. A Revolução Republicana de 1817: em busca de uma cultura constitucional brasileira. REJUR - Revista Jurídica da UFERSA, Mossoró, v. 1, n. 2, p. 57-67, ago./dez. 2017. https://doi.org/10.21708/issn25269488.v1.n2.p57-67.2017

COSTA, Célio; LEMES, Amanda; MONTAGNOLI, Gilmar. Processo civilizador e legislação: considerações sobre as Ordenações Portuguesas. Revista Educação e Fronteiras On-Line, v. 1, p. 118-129, 2011. Disponível em: https://ojs.ufgd.edu.br/ index.php/educacao/article/view/1454/863 Acessado em: 02 de março de 2021.

CRUZ, Guilherme Braga da. O direito subsidiário na história do direito português, in: Revista Portuguesa de História, Coimbra, n. 14, p. 177-316, 1974. https:// doi:10.14195/0870-4147_14_6

FARIA, Eduardo. Novo dicionário da língua portuguesa. $4^{\mathrm{a}}$ ed. v. 1. Rio de Janeiro: Typographia Imperial e Constitucional, 1859.

FARIA, Eduardo. Novo dicionário da língua portuguesa. $4^{\mathrm{a}}$ ed. v. 2. Rio de Janeiro: Typographia Imperial e Constitucional, 1859b.

FERNANDES, Antonio Scarance. Teoria Geral do Procedimento e o Procedimento no Processo Penal. São Paulo: RT, 2005.

FERREIRA, Manoel Lopes. Pratica Criminal, expedida na forma da praxe observada neste Reyno de Portugal, e illustrada com muitas Ordenaçoens, Leys Extravagantes, Regimentos, e Doutores, e em quatro Tomos destribuida. Porto: Officina de Antronio Alves Ribeyro Guimaraens, 1767.

FOUCAULT, Michel. A vida dos homens infames. In: FOUCAULT, Michel. Estratégia, poder-saber. Ditos e escritos IV. Rio de Janeiro: Forense Universitária, 2003. p. 203-222.

FREIRE, Pascoal José de Melo. Instituições de direito criminal português. Tradução de Miguel Pinto de Menezes. Boletim do Ministério da Justiça, n. 155-156, Lisboa, Ministério da Justiça, 1966.

GILISSEN, John. Introdução histórica ao direito. Lisboa: Fundação Calouste Gulbenkina, 1979.

GIULIANI, Alessandro. Il concetto di prova. Contributo alla logica giuridica. Milano: Giuffrè, 1961.

GIULIANI, Alessandro. Prova in generale Filosofia del diritto. Enciclopedia del diritto. v. 37. Milano: Giuffrè, 1988. p. 518-579. 
HESPANHA, António. História das Instituições - Época medieval e moderna. Coimbra: Editora Almedina, 1982.

HESPANHA, António. Cultura jurídica europeia: síntese de um milênio. Florianópolis: Fundação Boiteux, 2005.

HESPANHA, António. Direito moderno e intertextualidade: direito próprio e direito comum em «De Jure Lusitano» (1645), de Mateus Homem Leitão. In: RIBEIRO, Maria Manuela Tavares (org.). Outros combates pela história. Coimbra: Imprensa da Universidade de Coimbra, 2010. p. 473-498.

LEITÃO, Matthaeo Homem. De Jure lusitano: tomus primus in tres utiles tractatus divisus 1. De grauaminibus,2. De securitatibus, 3.de inquisitionibis. Coimbra: Apud Franciscum de Oliveyra Univers. Typ., 1736.

LEMOS, Carmem Silvia. A justiça local: os juízes ordinários e as devassas da Comarca de Vila Rica (1750-1808). Dissertação (mestrado em história) - Universidade Federal de Minas Gerais, Belo Horizonte, 2003.

LÉVY, Jean Philippe. La hiérarchie des preuves dans le droit savant du Moyen-Âge depuis la renaissance du droit romain jusqu'à la fin du XIVe siècle. Paris: Sirey, 1939.

MARTINS, Lucas Moraes. Uma genealogia das devassas na história do Brasil. In: XIX Congresso Nacional do CONPEDI, 2010, Fortaleza. Anais do XIX Congresso Nacional do CONPEDI. Fortaleza: Fundação Boiteux, 2010.

MARCHETTI, Paolo. Testis contra se. L'imputato come fonte di prova nel processo penale dell'età moderna. Milano: Giuffrè, 1994.

MELLO, Evaldo Cabral de. A outra independência (o federalismo pernambucano de 1817 a 1824). São Paulo: Editora 34, 2004.

MENDES DE CASTRO, Manoel. Repertório das Ordenações do Reyno de Portugal novamente recopiladas com as remissões dos doutores todos do Reyno, que as declararão, \& concordía das Leys de partida de Castella. Coimbra: Officina de Manoel Dias, 1661.

MENDES DE CASTRO, Manoel. Practica Lusitana, advocatis, iudicibus, vtro qve foro qvotidie versantibus, admodum utilis, \& necessaria. Olysipone: Apud Georgium Rodericum, 1619.

OLIVEIRA, António Braz de; MARINHO, Maria José. Devassa a que mandou proceder Sua Magestade no território do Alto Douro pelo Desembargador Antonio de Mesquita e Moura. Lisboa: Biblioteca Nacional, 1983.

PEREIRA e SOUSA, Joaquim Jose Caetano. Primeiras linhas sobre o processo criminal. $3^{\text {a }}$ ed. Lisboa: Typo. Rollandiana, 1820.

PEREIRA e SOUSA, Joaquim Jose Caetano. Esboço de hum diccionario juridico, theoretico, e practico: remissivo às leis compiladas, e extravagantes. Lisboa: Typographia Rollandiana, 1825. 
PRECIOSO, Daniel. Absolvida pela loucura: a mulata Rita e o furto dos brincos de uma imagem sagrada (Vila Rica, 1760). Temporalidades, v. 2, p. 110-119, 2010. Disponível em: https://periodicos.ufmg.br/index.php/temporalidades/article/ view/5408/3335 Acessado em: 02 de março de 2021.

PIERANGELLI, José Henrique. Processo Penal: evolução histórica e fontes legislativas. Bauru: Jalovi, 1983.

PIERANGELI, José Henrique. Códigos Penais do Brasil: evolução histórica. 2. ed. São Paulo: Revista dos Tribunais, 2001.

PUNTONI, Pedro. Da libra ao real: sobre a formação do sistema monetário português (1185-1580). Revista de História, São Paulo, n. 178, p. 1-38, 2019. https:// doi.org/10.11606/issn.2316-9141.rh.2019.141351

REIS, João José. Rebelião escrava no Brasil: a história do levante dos malês. São Paulo: Brasiliense, 1986.

REIS, João José. Recôncavo rebelde: revoltas escravas nos engenhos baianos. Afro-Asia, v. 15, p. 100-126, 1992. http://dx.doi.org/10.9771/aa.v0i15.20837

RIBEIRO, Ludmila Mendonça; DUARTE, Thais Lemos. Do processo penal colonial a reforma processual penal de 2008: análise sócio-histórica do Sistema de Justiça Criminal brasileiro. Interseções - revista de estudos interdisciplinares, v. 13, n. 1, p. 40-64, 2011. Disponível em: https://www.e-publicacoes.uerj.br/index.php/ intersecoes/article/view/4604/3403 Acessado em: 2 de março de 2021.

SABADELL, Ana Lúcia. Tormenta Iuris Permissione. - Tortura e Processo Penal na Península Ibérica. Rio de Janeiro: Revan, 2007.

SANTOS, Edenir Vitória de Araujo. Auto de Devassa do crime de descaminho e contrabando: o inquérito, a verdade e os sujeitos históricos nos jogos do poder (Minas Gerais, Brasil, 1792). In: V Colóquio Nacional Michel Foucault: a arte neoliberal de governar e a educação. Uberlândia: EDUFU, 2017.

SALGADO, Karine. O Direito no Brasil Colônia à Luz da Inconfidência Mineira. Revista Brasileira de Estudos Políticos, v. 98, p. 479-494, 1 jul. 2008. https:// doi.org/10.9732/82

SCHMOECKEL, Mathias. Humanität uns Staatsräson. Die Abschaffung der Folter in Europa und die Entwicklung des gemeinen Strafprozeß- und Beweisrechts seit dem hohen Mittelalter. Köln: Böhlau, 2000.

SCHWARTZ, Stuart B. Burocracia e sociedade no Brasil colonial: a suprema corte da Bahia e seus juízes: 1609 - 1751. $1^{\text {a }}$ ed. Trad. Maria Helena Pires et al. São Paulo: Editora Perspectiva, 1979.

SCHWARTZ, Stuart B. Segredos internos: engenhos e escravos na sociedade colonial, 1550-1835. São Paulo: Companhia Das Letras, 1985. 
TAVARES, Francisco Muniz. História da revolução de Pernambuco em 1817. 3. ed. Recife: Imprensa Industrial, 1917.

TEIXEIRA, Maria Lúcia Resende Chaves. As cartas de seguro: de Portugal para o Brasil colônia - O perdão e a punição nos processos-crimes das Minas do Ouro (1769-1831). Tese (Doutorado em História Social) - Faculdade de Filosofia, Letras e Ciências Humanas, Universidade de São Paulo. São Paulo. 2011.

VALIM, Patrícia. O Tribunal da Relação da Bahia no final do século XVIII: politização da justiça e cultura jurídica na Conjuração Baiana de 1798. Tempo, v. 24, n. 1, p. 117-139, 2018.

VALASCO, Alvaro. Decisionum Consullationum Acrerum iudicatarum in Regno Lusitanae. Venetiis: Bernardum Iutam, Ioan. Bapt. Cioottum \& Socios. 1609, consultatio XXI, no 10 .

WEHLING, Arno; WEHLING, Maria José. Direito e Justiça no Brasil Colonial - O Tribunal da Relação do Rio de Janeiro (1751-1808). Rio de Janeiro: Renovar, 2004.

\section{Additional information and author's declarations (scientific integrity)}

Acknowledgement: Agradecemos a historiadora Déborah Kelman de Lima, especialista em paleografia, que colaborou para a análise dos processos apresentados neste texto.

Conflict of interest declaration: the authors confirm that there are no conflicts of interest in conducting this research and writing this article.

Declaration of authorship: all and only researchers who comply the authorship requirements of this article are listed as authors; all coauthors are fully responsible for this work in its entirety.

- Ana Lúcia Sabadell: conceptualization, methodology, data curation, investigation, writing - original draft, validation, writing - review and editing, final version approval. 
- Julio Cesar Costa Manoel: conceptualization, methodology, data curation, investigation, writing - original draft, validation, writing - review and editing, final version approval.

Declaration of originality: the authors assure that the text here published has not been previously published in any other resource and that future republication will only take place with the express indication of the reference of this original publication; they also attest that there is no third party plagiarism or self-plagiarism.

\section{Editorial process dates}

(http://www.ibraspp.com.br/revista/index.php/RBDPP/about/editorialPolicies)

- Submission: 30/05/2021

- Desk review and plagiarism check: 01/06/2021

- Review 1: 20/06/2021

- Review 2: 22/06/2021

- Preliminary editorial decision: 29/06/2021

- Correction round return: $11 / 07 / 2021$

- Final editorial decision: $16 / 07 / 2021$

\section{Editorial team}

- Editor-in-chief: 1 (VGV)

- Associated-editor: 1 (RS e MG)

- Reviewers: 2

\section{HOW TO CITE (ABNT BRAZIL):}

SABADELL, Ana Lúcia; MANOEL, Júlio Cesar C. Considerações sobre as Inquirições Devassas no Brasil: os casos do Recôncavo Baiano - Séculos XVIII e XIX. Revista Brasileira de Direito Processual Penal, vol. 7, n. 2, p. 10191056, mai./ago. 2021. https://doi.org/10.22197/rbdpp.v7i2.624

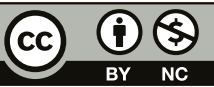

Esta obra está licenciada com uma Licença Creative Commons Atribuição-NãoComercial 4.0 Internacional. 